Meta

Journal des traducteurs

Translators' Journal

\title{
Being ACTIVE in Legal Translation and Interpreting: Researching and Acting on the Spanish Field
}

\section{Esther Monzó}

Volume 50, numéro 4, décembre 2005

Pour une traductologie proactive - Actes

For a Proactive Translatology - Proceedings

Por una traductología proactiva - Actas

URI : https://id.erudit.org/iderudit/019922ar

DOI : https://doi.org/10.7202/019922ar

Aller au sommaire du numéro

Éditeur(s)

Les Presses de l'Université de Montréal

ISSN

0026-0452 (imprimé)

1492-1421 (numérique)

Découvrir la revue

Citer cet article

Monzó, E. (2005). Being ACTIVE in Legal Translation and Interpreting:

Researching and Acting on the Spanish Field. Meta, 50(4).

https://doi.org/10.7202/019922ar

\section{Résumé de l'article}

La traduction n'est pas une profession. Il s'agit de la conclusion d'une étude développée par l'auteur parmi des traducteurs juridiques espagnols. Mais, il existe des stratégies que les chercheur peuvent employer pour promouvoir l'intérêt social, culturel et économique de ces professionnels, surtout en appliquant la méthodologie de recherche-action de Lewin. Cet exposé présente un projet de recherche qui est en processus de développement par le groupe ACTIVE, pour décrire et expliquer une petite partie du champ de la traduction et l'interprétation - la partie destinée à la communication intersystème du droit. En explorant et en développant les intérêts et les stratégies des traducteurs et interprètes certifiés dans le contexte espagnol, on essaie d'améliorer les conditions de leur pratique professionnelle. 


\title{
Being ACTIVE in Legal Translation and Interpreting: Researching and Acting on the Spanish Field
}

\author{
ESTHER MONZÓ ${ }^{1}$ \\ Universitat Jaume I, Castelló, Spain \\ monzo@trad.uji.es
}

\begin{abstract}
RÉSUMÉ
La traduction n'est pas une profession. Il s'agit de la conclusion d'une étude développée par l'auteur parmi des traducteurs juridiques espagnols. Mais, il existe des stratégies que les chercheurs peuvent employer pour promouvoir l'intérêt social, culturel et économique de ces professionnels, surtout en appliquant la méthodologie de recherche-action de Lewin. Cet exposé présente un projet de recherche qui est en processus de développement par le groupe ACTIVE, pour décrire et expliquer une petite partie du champ de la traduction et l'interprétation - la partie destinée à la communication intersystème du droit. En explorant et en développant les intérêts et les stratégies des traducteurs et interprètes certifiés dans le contexte espagnol, on essaie d'améliorer les conditions de leur pratique professionnelle.
\end{abstract}

\begin{abstract}
Translation is not a profession. That was the conclusion of a study carried out by the author among Spanish legal translators. However, there are strategies which may be used by researchers in order to promote the social, cultural and economic interests of these professionals, mainly by applying Lewin's methodology of action-research. This paper presents a research project currently being carried out by the ACTIVE team, which seeks to describe and explain a small part of the translation and interpreting field - that devoted to the intersystemic communication of law. By exploring and promoting the interests and strategies of certified translators and interpreters in the Spanish context we aim to improve their professional practice conditions.

\section{MOTS-CLÉS/KEYWORDS}

ACTIVE project, legal translation and interpreting, intersystemic communication of law, Spanish
\end{abstract}

\section{Introduction}

This paper focuses on a research project (ACTIVE), which is currently in progress, and which aims to describe and explain - as Bourdieu would say - a small part of the translation and interpreting field, namely, that devoted to the intersystemic communication of law in official contexts. In this paper I will give some notes on the present situation of the profession in Spain - assuming we can refer to this sector as such - and I will do that from a theoretical point of view which synthesises some of the proposals of the sociology of professions and Pierre Bourdieu's economy of practice. After outlining this framework, I will then go on to explore how the ACTIVE project aims to change the socioeconomic situation of professional translators and interpreters in our country. In order to support this point, I will give some methodological notes on action-research and also point out how this framework can help us - albeit with little steps - to reach a much more advantageous situation for translators and interpreters in Spain.

First of all, I should draw attention to the fact that the situation of professional translation in Spain is far from the one reported in countries like Canada (Delisle 1998: 360). Professional cohesion, social prestige, fees, even working conditions, are all far from optimal. In our context, translators' voices are barely heard in issues which directly affect their practice. This is, for instance, the case with the reforms adopted in laws of procedure. Before the reform, any person who did not know the Spanish language was entitled to a sworn translator and interpreter and, if noone could be found for the pair of languages involved, one should be appointed from those with a 
relevant degree. After the reform, however, the court may temporarily appoint as a sworn translator and interpreter anyone who declares to have a sufficient knowledge of the foreign language and this person is bound by oath to produce accurate renderings.

This new regulation has led to more than just a few cases where the police and the court hear arrested people's statements through other arrested people (Escudero 2001), or even - and this is also a real case - through the butcher working in front of the court who happens to be Arabian and has only a basic command of Spanish. Even when the so-appointed interpreters are not personally involved in cases, who determines whether their interpreting is competent enough? Noone does, and this definitely has a detrimental effect on arrested people's rights. Faced with the anger of translator and interpreter associations, the administrative bodies concerned in the matter argued that no professional sworn translator from Arabic had been available is those cases, even though these sworn translators had not received any calls or notice whatsoever to go to court and were willing to do so.

This is but one example from the public sector, but what about the private sector? The State has vested in the official sworn translator a 'precautionary and preventive security' function to work with the public. This term has come to have rather negative connotations in international politics, but in the Spanish legal system it refers to a mechanism whereby certain agents in the legal field prevent conflicts and litigation in court by ensuring agreement between parties and preventing possible misunderstandings, thereby contributing to efficiency and also economic growth. They are thus portrayed as neutral parties with interpersonal duties and a heavy responsibility in ensuring communicative success. Consequently, any biased or in any other way undue performance must be remedied personally, which means that they can be sued for any professional action harming their clients' rights.

These agents are therefore special in the sense that they are mediating between the State and the public, as are the corps intermédiaires identified by Durkheim (see, for instance, Durkheim 1937/1992). The term for this function was not coined with our profession in mind, but it covers the function the State assigns to sworn translators and interpreters. However, whereas other agents with this same function are taken care of by the State, translators and interpreters are not. Notaries - not to be confused with Notaries Public - are explicitly recognised as fulfilling this function in the legal system and are therefore provided with favourable regulations which guarantee their independence and which allow them, among other things, to certify the faithfulness of translations from the languages they may know. In contrast, translators' and interpreters' needs are clearly being ignored by law, when not directly stepped on.

This leaves the sector at the mercy of the market and, in a culture where the State is rather interventionist, this causes a problem. While other sectors with similar claims are backed by statute law, we are not and this is sometimes clearly damaging to our interests. No wonder lawyers, but also lay people, openly declare to translators that their fees and terms are excessive for a service anyone could do by themselves as quickly as they type. We receive recognition neither by the State nor by the public or the market.

This situation is rather stressing for professionals. Should we surrender to market pressures and accept we are incompetent if we cannot get a specialised 3000 word text done overnight or within a few hours? I am a translator myself and, of course, my thoughts on the matter were that we were being dealt with rather improperly. However, as scholars we need to know what sort of rationale is supporting this situation and, as scholars engaged with the professional community, we need to know whether it can be changed and, if that is the case, how to go about doing so.

This concern gave rise to a first study, which was presented as a Ph.D. dissertation in 2002 (Monzó 2002). The purpose was to find out whether we are to be considered a profession and can therefore claim similar social privileges and resources as are allocated to, say, lawyers, or whether we must instead be compared with other socially subordinate activities which support the development of the main ones, properly called 'professions'.

This question led me to the literature on the sociology of professions. My aim was to define what a profession was, as a sociological phenomenon, so as to map the results against our own activity and find out what sort of profession we were, and whether we could cherish any hopes of improving the present situation. In order to achieve this aim I first needed to describe how the 
translation field worked and so I turned to Bourdieu's theory of practice, which provided me with a very useful framework for analysis.

\section{Are translators and interpreters professionals?}

Regarding the first of these needs, it must be said that no thorough consensus exists on what should be termed as a 'profession', although there seems to be a growing trend towards considering an increasingly wider set of labour activities. From a historical point of view, by the end of the 19th century, some occupations had acquired a social relevance earlier reserved to nobles and clergymen. In those industrialised days, most jobs entailed a minimum amount of participation, the activity of workers being highly limited to monotonous and repetitive tasks. In this context, some privileged people kept an overall perspective and had the power to take decisions regarding their work; the tasks they performed were cognitive rather than manual, and they maintained direct relations with the consumers of the service they provided. The distinctions lead to reserve this term in the English vocabulary to labour activities with a heavy intellectual, technical or scientific basis (Perkin 1989).

The phenomenon caught the attention of sociologists and the first contributions to a sociology of professions were highly influenced by functionalist (Carr-Saunders and Wilson 1933) and structuralist (Wilensky 1964) perspectives of society. This derived in optimistic - maybe even naïve - and simplistic views of what professions are or represent in society. Thus definitions of professions highlighted moral values - as well as being heavily influenced by Durkheim's sociology - and tended to consider as such only those labour activities which had already reached a welfare status, specifically medicine and law. Professions were groups satisfying the needs of society in the same way as an organ satisfies a need of the body. From this point of view, the set of needs a society can have is determinate and therefore the number of labour activities claiming a professional status is also finite. And that is the reason given for closing the scope of action of those professionals who have attained a prominent status in society. However, this scope was clearly too narrow and by avoiding the study of other kinds of activities most definitions particularised traits which were also present in other occupations. Mostly definitions attempted to include as many traits as possible - sometimes up to 23 different characteristics (Millerson 1964) in order to set boundaries which other occupations could not cross over. That is why these trends are also collectively named the 'feature approach'. To sum up, the three basic characteristics attributed to professions by these groups of scholars were:

- KNOWLEDGE. This is perhaps the only feature whose centrality has not yet been overridden. Knowledge is the basis of a profession - society relies on a profession to solve a particular problem according to a particular solution. This solution is based on a common view shared by the whole professional community and professionals master a systematic administration of this world view. By relying on professionals to work exclusively in a field of expertise, society obtains a sort of intellectual guarantee covering any dealings with its needs. One should not forget that mastering such practical and abstract knowledge requires a long-lasting training and, therefore, also a vocational attitude on the part of the professional, who sacrifices several years so as to serve society afterwards.

- FRATERNITY. Following Durkheim's interest in ethics, a set of values is attached to professionals and they are seen as embodying the 'communities' of modern society. As happened in former times within villages or towns, fellow professionals act as socialising entities for their own professional groups. At the same time, the profession as a community represents a repository of values which guarantees the morals of society are being protected in solving common problems, even though no lay member of society can check for the goodness or badness of professional acts, due to the specialised training and knowledge required for practice.

- Self-Regulation. A profession is a community which has been given the power to regulate matters affecting its own field of expertise. This provides for autonomy and allows professionals 
to act with independence both from the market and from the State. Both of them would act as forces with their own interests, different from those of the client, which are the only ones a professional should take into account. With self-regulation, the need for a body of experts specialised in creating and promoting suitable regulations arises. They will ensure the professional work is only sanctioned and evaluated by peers, who are the only ones who can test a professional solution. Thus, self-regulation works as a structural guarantee for the service the professional offers.

This approach provides a rationalisation for professional privileges, and keeps those privileges in the hands of a few already-established professionals. Such a point of view has been revisited and highly criticised by other scholars, influenced by Weber's social theories. Their view of society is far more dynamic and they see intentions behind structures, mostly the intention to acquire power - and also resources, of course. This power is mainly acquired through the organised monopoly of knowledge. Under this perspective a profession attempts collective extortion, whereby professionals hold in their hands a service needed by society, and they organise themselves so as to demand resources (usually in great amounts) as compensation. The acquisition, increase or maintenance of social power is achieved through a twofold movement named 'social closure', whereby professions are isolated from one another and from society itself (Weber 1925/1976: 177, Parkin 1974). This social closure works by attracting those resources a given society can have (usurpation) and excluding non-members from the benefits they acquire (exclusion).

All this change in perspective allows for a new concept to come to the front, that being 'professionalisation' (Larson 1977). Only from a dynamic view of society can a non-profession become a profession. The number of activities claiming this rank is no longer limited and any one of them goes through non-professional stages and takes different steps before becoming established. By studying these different steps, scholars and professionals attempt to discover and design professionalisation projects, that is, to find out what an occupation has done in order to become a profession, or, also, what an occupation has to do in order to become a profession. A common idea is that any profession aims to establish an area of exclusivity over a given activity. To reach this goal, they must control supply, that is to say, they have to identify competent members as professionals and determine how to exclude those who have not been declared competent. A common pattern seems to be to institutionalise knowledge through establishing credential requirements (e.g. diplomas), to control access to practice through barriers which ensure a common set of values are shared by the members of the profession (e.g. college training), and to gain exclusivity in the market for those who have obtained competence in the previous steps (Abel 1989: 18-19). Once they establish the monopoly they can begin 'extorting' both the public and the State, in search of better conditions.

A third group of sociologists would see professions as forming a system. We can quote Durkheim, who points out that professions become aware of themselves as a community and gain a shared identity only when they have to protect their interests against those of others (Durkheim 1938/1977: 81). Along these lines, several authors contribute to a common idea of interdependency among professions and an inevitable instability in the evolution of any one of them. According to these views, the system of professions (Abbot 1988) is to be seen as a field where interests clash both between different professions and between fellow professionals. Different groups try to establish their own control over the same work, that is to say, over the same tasks which society needs to have done (solve conflicts, heal our bodies, save our souls, and so on). The more exclusive this control is the more stable resources will be, of course. However, any movement they make will affect other groups trying to do just the same - that is, to gain stability, or maintain or improve their conditions. Conflict, or fight, is thus endemic and who wins will depend on what sort of solution they offer to fulfil society's needs.

The different groups will offer different solutions, based on different knowledge. Those who best sell their solution to society, that is, those who best adapt their answers to the values of society will succeed and gain a dominant position in the system of professions whereas those who cannot convince the public will fail, and sometimes may even disappear or just go on fighting in this field until they discover a better solution, gain the public's approval or find a vacancy and make a 
shift. This vacancy may be a task previously unidentified by society but which arises as a new need which no-one was fulfilling, or it could be a task which was being carried out by another profession which may have moved on to a specialisation or withdrawn into a specific area leaving a part of the work orphan. The new group can reinterpret the task and keep it under its own jurisdiction as long as it manages to obtain legitimacy (Haskell 1984), that is, as long as society finds its solution logical, rational, scientific or attaches to it any other value considered as positive in the particular context.

What a profession needs to become consolidated is to be preferred by society, especially by its clients, who would appreciate clear and efficient practices which can be found in all

professionals. Let's take as an example a rather common situation with a widely known profession. If we go to the doctor it is because we think they will solve our problem, because we know doctors usually do, and so if we have a common idea of what doctors do, are and look like we will expect the doctor we visit to behave like others do, and to give us a solution which is like other previously effective solutions. We cannot confirm beforehand whether this will be effective, but we can recognise some common patterns which will make us trust (a common language, for instance). Of course, a particular shared knowledge lies at the core of any solution a doctor may offer us, but society would need to become specialised in all matters to be able to recognise whether a doctor or any other professional really shares that common knowledge which makes a profession's solutions succeed. We cannot do so, and therefore we trust.

Legitimacy and knowledge are the key issues in the evolution of any profession. Knowledge is the core of the solution and, consequently, the reason for the very existence of any profession. The cognitive basis is also the basis for interprofessional conflict. Fights between different professions trying to achieve jurisdiction over a task are fights to make their own interpretations of and solutions for the same problem prevail over those of others. Behind any one of the three main phases which articulate any intellectual service - diagnosis, inference and treatment - there is a world view shared through socialisation by all the members of a profession. This world view is revealed to the public through common, clear and efficient practices (Freidson 1986), as well as a common language, which leads the public to identify and respect the profession and its jurisdiction. In this sense, knowledge brings legitimacy.

In order to be competitive, professional knowledge must be continually updated and adapted to changes in the system in order for the profession, as a group, to keep face. This is the reason why research and research centres become essential, along with the transfer of new solutions to new professionals through training centres and nationwide journals and associations. The people working in these associations, specialised in managerial tasks, will be able to use this newly acquired knowledge to defend the group against others' interests for the same tasks. New technologies, new groups, new professions, changes in public policy, internal fights, and so on, will all affect the whole system of professions, offer possibilities for improvement and also set new dangers for the group's survival. An organised internal partitioning will make the group ready for these challenges. However, a profession whose members are at odds, where rank-and-file professionals avoid contact with the administrative and knowledge elites will have a rather weak position in the system.

This is definitely the case with Spanish sworn translators and interpreters. The survey I carried out in a previous work (Monzó 2002) ${ }^{2}$ showed us that a very small number of these professionals are registered with any sort of association, and even fewer participate in the activities organised by the very few activists currently working in the field. Furthermore, although a reasonable number of sworn translators and interpreters are members of e-groups, only a few of them participate in the discussions. On the other hand, professionals commonly shun the invitation to take part in research studies which require their participation (Monzó 2005a), although it must be said that such studies are relatively few. All in all, not only are the different groups (administrative, intellectual, rank-and-file professionals) at odds with each other, but there are also further internal conflicts. For instance, controversy exists between rank-and-file translators and interpreters with and without a degree in translation and interpreting - something which sets even more pressure against the smooth running of work and the success of the field. 
Under these circumstances, socialisation becomes defective and a shared identity is something we cannot attribute to our professionals. Even though our studies in this sense are just at the beginning, we are interviewing translators and examining how they represent themselves in their discourse as part of a community and, when they do this at all, the identification of a translator with fellow professionals is very weak. Therefore it becomes impossible for society to recognise sworn translation and interpreting as a distinct jurisdiction being run by a group of professionals, since every interaction does not represent a common structure.

Unqualified practice is thus inevitable. Anyone can feel translation and interpreting is a vacancy in society which someone must fill, and a poor awareness of the knowledge required and what constitutes quality in intercultural mediated communication makes the public consider anyone suitable, as long as they have a (maybe even vague) knowledge of the language. This is also due to a defective institutionalisation of the knowledge basis. In these very moments, the Spanish university system is undergoing a reform with a harsh jurisdictional fight between translation studies and adjunct areas - such as language studies - which are trying to occupy the former's jurisdiction. All in all, the translation and interpreting jurisdiction is rickety at all levels. This instability of the translation and interpreting jurisdiction has, in turn, a wide influence on the absence of a shared identity among professional translators and interpreters.

Nevertheless, the community survives and the constant changes and jurisdictional fights its agents must undergo could offer a productive field of study for the sociology of professions, thus allowing another opportunity for the translation turn. In order to find the rationale behind the present situation and the constant changes, we need ethnographic studies on the professional work being performed in order to obtain data and new interpretations of the jurisdictional fights translators and interprets must endure.

\section{The economy of practice}

These highly longed for studies may well be structured around Pierre Bourdieu's economy of practice (see, for instance, Bourdieu 1971, 1972, 1979, 1986). Indeed, the concepts designed by this sociologist are proving to be most helpful in the field of translation studies (Simeoni 1998, Sapiro 1999, Inghilleri 2003, Monzó 2005b). In connection with what we have been saying about the sociology of professions, the applicability of Bourdieu's theories is almost self-evident. Internal and external conflicts within and between jurisdictions in the sociology of professions are parallel to the fights between agents and fields in Bourdieu's views of society. Professions trying to make their own solutions prevail over those of others (for the same social problem) find their parallelism in Bourdieu's agents and classes pushing for their own conflicting interests. The internal differences among professionals are similar to the internal structure of fields, where social agents have different positions which define their possibilities to obtain resources and power, or 'capital', in Bourdieu's terms. Legitimacy of the different professions can be better understood if thought of as symbolic capital attributed to agents and fields, and incorporated in habiti. Success and consolidation of professions can also be seen as the domination of some fields, groups and agents over others. And those are but a few examples of the parallelisms.

To read the sociology of professions from the clear structure of Bourdieu's analysis offers a very comprehensive path to follow, and a way of avoiding the vagueness of references to context, milieu, etc. by working with more precise categories. Field and habitus are by far the most frequently used, but also nomos, doxa, illusio, distinction, the different types and forms of capital, the solution he gives to the conflict between objectivity and subjectivity, the play between the structure and the individual, among many other proposals, are very powerful tools for describing and explaining the social world. Moreover, the focus of Bourdieu's sociology on the critique of society in order to wake it up and introduce social justice in social practices can help translators and interpreters to attain better conditions in which to conduct their professional practice.

Bourdieu's theories are becoming well-known in the field of translation studies so I will not go into detail explaining its basic concepts. I will only outline them so as to be able to situate the aims of the ACTIVE project. Bourdieu thinks of society as a field of forces and fights, where agents meet and conflict, using the means they have available to them according to the position they 
occupy in the structure of power. Each of these fields has its own values and regulative principles which distinguish one another and set the boundaries of this social arena. The agents act as members of a field and follow these values which have been introduced in their personality by means of enculturation or socialization at schools, in their interaction with others, etc. ${ }^{3}$ and they do so from a position which allows them to dominate some agents and be dominated by others, always fighting for one's own interests and for the field's interests.

Under this perspective, conflict is endemic since agents are always trying to acquire, maintain and increase the specific profits (money, knowledge, prestige, and so forth) that are at stake in the field they reside in. These profits may be different forms of capital (economic, cultural or social), either material (food) or symbolic (prizes). Social practice - and fight - is always conditioned by the agents' habiti, that is, how they have incorporated the structure of positions and relations to their own practices (what they think is possible in society, what have they ever been able to think of as possible, and so on) and how many resources they have which are of any value in the particular field they are in (the capital they have acquired as individual or as members of a group). This makes it easier for, say, the son of a president to become president when compared to the son of a peasant, because they start their social lives with different amounts of capital (the president's son will definitely have more social, and maybe economic, capital at the very outset) and so their possibilities of investment grow differently as they live their lives. Even in the case that the president's son does not invest in cultural capital at all and the peasant's son does his best to gain this sort of goods, the field of politics balances the quantities and types of capitals according to its own rules and this capital may be consigned to a subsidiary position in this particular field. The peasant's son may not know the rules of the game because he has not had the opportunity to incorporate this knowledge - something which the president's son has definitely had the chance to do; he therefore cannot change his strategy and thus his habitus will make him unsuitable to preside over a nation.

In the case of translators and interprets, it is the cultural capital (the cognitive task which configures the jurisdiction we are fighting for) which provides us with resources from other sectors of society. This cultural capital is the knowledge and practice of a very specific type of intercultural communication. What we are doing right now in the Spanish context is fighting with other fields in order to maintain this function in society. But we need to see what strategies (which may be focused on either maintaining, increasing or acquiring new capitals) ${ }^{4}$ are being implemented to promote our interests, since the situation is definitely unstable and intervention may be needed for the group to survive.

\section{The ACTIVE project}

The ACTIVE project (which stands for Analysis of the Field of Translation and Interpreting in Specialised Areas, in Catalan) aims to apply the framework of analysis provided by the economy of practice to the work of professional official sworn translators and interpreters in order to obtain data which may help us in a professionalisation project. Furthermore, we also take in Bourdieu's engagement in social change, and we do so by adopting Lewin's action-research as a framework (I will deal with this methodology later on). Our aim is to describe and explain how the field of sworn translation and interpreting works, especially in those aspects which sociology finds crucial in the evolution of a profession. We will take this description and the conclusions deriving from it as a diagnosis in order to design and implement actions which may help improve the social conditions of the profession.

The description is structured around the following lines:

- The social geography of the field.

- The types and amounts of capital.

- The relative autonomy of the field.

Regarding the first of these topics, we want to discover who the residents of this social arena are, the agents acting in the field as consumers or producers (individuals, social classes, institutions, 
other fields, and so forth). We are also trying to describe how the residents are distributed in the field regarding the positions they occupy and what the relations between them are (domination, subordination, coordination or juxtaposition). Another aim would be to find out what battles are driven between orthodoxy or conservation and heresy or subversion and what the interests driving those battles are.

In relation to the types and amounts of capital the agents need to play the game as legitimate players, we are interested in discovering how the different types of capital (economic, social, cultural) are balanced and distributed in the field among the agents. Another point is to determine how material and symbolic resources - as symbolic capital (prizes, prestige, reputation) - are distributed and what investment strategies the agents play to augment their position in the field.

Finally, in order to describe and explain the autonomy of the field from the field of power (the state and dominant economic classes), we will study how the interest of this field is communicated to the field of power, and how the field of power intervenes in society or other fields to help serve its interests. Conversely, we also need to know how the field of power intervenes in this field in order to promote the interests of others.

Central to this description will be the role played by the professional task, the communication materialised in a translated utterance. In previous works, I termed these translated utterances as 'transgenres' (Monzó 2002). As genres, they also constitute models for communication, which in this case are specifically related to prototypical translation situations. As systems, they share features which establish a strong link between them and which can be described by reference to textual, situational and cultural material. This link distinguishes these particular utterances from original texts both in source and target systems since they are specific to translation professionals. Transgenres constitute the task of professional translators and interpreters, and are the product of the application of knowledge which justifies the very existence of any profession. Previous studies have shown (Monzó 2002) how legal translations textualise according to strategies which are not to be found in source texts or in target systems, and are therefore particular to the translation field. What we should study from this is whether translation as a profession has standardadised this product and whether we can find regularities which can specifically be referred to different translation situations (where the relation between translator and client can be traced) and, perhaps more importantly, to the representations of these situations that have been incorporated in translators' habiti. We consciously chose not to study a specific language common to translation as a whole regardless of the requirements set by translation briefs and therefore depart from studies interested in how 'translationese' is materialised in texts (Baker 1998a). Studying translated utterances by reference to their own situation of production and consumption and establishing typified groups among these situations so as to classify transgenres can give us an interesting point of departure from which to measure the inference translators and interpreters as professionals do before applying the corresponding treatment to the particular case.

As has been suggested, the analysis of habiti is also needed in order to describe the field. It could not be otherwise, since communication occurs between agents and it is these agents' perception of the structure and their relationship what determines their interaction. Accordingly, our project has been set up to analyse the incorporation of the structure in the representations agents have of their place in the field, and that of others. Of course, this subjective analysis will be faced with their respective objective positions. Again transgenres will be an important part of the study and textualisations will be compared taking into account the real and perceived positions in the field of the agents involved in the particular instance of communication.

In following phases, this first analysis of the habiti will help us show the agents how changes in structure perception can help change the structure itself, and how changes in habiti cause changes in textualisations and, from there, in the solution the profession offers to society, which is its door to legitimating a jurisdiction of its own. In this regard, standardisation of practices (of transgenres) is a powerful tool towards professionalising the field, and, of course, this standardisation must reflect practices which can be perceived by the public as logical, rational and scientific, derived from an abstract but at the same time applicable and efficient knowledge - in other words, we need to extend quality translation practices. Some of the data we have already gathered show that quality is not always the priority in the work of sworn translators and interpreters. Indeed we have paid for sworn 
translations which included several obvious mistakes which may harm the client's interests. These translations were not accompanied by any comments on problems or difficulties but were given as final products.

This reinforces some of the conclusions of my previous work in the sense that the field of translation shows a hierarchy of capitals which is quite different from the one to be found in an established profession. That would lead us to characterise the translation field as a 'quasiprofession' or, perhaps, as a mercantile activity, instead of as a proper 'profession'. In the translation field, the economic capital would be the most important, the one habiti set to the front in daily practices, thereby relegating cultural capital to a second term (once the translators have established a client list and have enough work to earn a living, dedication to continuous training is almost forgotten and the only source of learning is daily practice and documentation, something which would be very poorly considered in professions). However, social capital ranks last and it is almost forgotten. Translators do not engage themselves in promoting their image as a group in society, or even in their most immediate milieu. As said, only a few, such as the president of the most important sworn translators and interpreters' association in Spain (ATIJC), do engage in such activities (Peñarroja 2004), although they can obviously benefit the whole field. We should consider in this sense that the power which a particular person may acquire is rather limited; even when charged with plena potestas agendi et loquendi and representing the group in front of others.

In contrast, a profession would rank capitals very differently. Economic capital would be ranked last and that would allow for the public to see a vocational focus in the people choosing this activity for a living. This leads society to attach a set of positive personal values to the group. Social capital would be next in importance and so professionals would invest a great deal of resources, both as individuals and as a group, in order to weave a network of social obligations which may help them ultimately access the field of power in order to obtain more favourable regulations, for instance. Such is the case with Notaries in Spain, and it is not the case with translators. Finally, first ranked would be cultural capital, as knowledge is the very basis of any profession. The capacity of professionals to innovate and create new knowledge which can be applied in the solution of social problems and which, at the same time, helps them distinguish their solution from that offered by other groups also helps society to distinguish professionals from non-professionals and it is therefore an essential feature of any group if it is to become a profession.

\section{Action-research for a change}

The situation is not really encouraging; nonetheless, we believe it can be transformed. Indeed we aim to change the conditions in which translators and interpreters work by committing our research to the professional field. In order to do so, we will adopt an action-research framework. This methodology has been introduced in the translation studies area through the applications developed in the field of pedagogy, something that is also called the teacher-as-researcher approach (Corey 1953, Hustler et al. 1986). Authors such as Hatim (2001) and Kiraly (2001) take this approach and suggest very interesting proposals for research. Both focus on practical problems and entail reflective planning, analysing professional behaviour and suggesting improved translation methods. This is definitely very useful but it is not what we understand by action-research since the link between research and profession has still not been established. We need implementations - the action in action-research - and this is what we find in the methodology Lewin (1946) first termed as action-research (see also Monzó 2005a).

Lewin's representation of society is in fact very similar to Bourdieu's, in the sense that both see the social arena as a field of forces. Lewin's interest in this representation lies in the change that can be produced through altering the pressure exercised by opposing forces. Both driving and resisting forces must be identified and the pressure exercised by them will determine whether there is a stable or a changing situation. Trying to influence these forces will help researchers and agents to produce reorientations in the field. The process of action-research can be explained in quite simple terms and Lewin defined it as a three-step spiral process of "planning, action and factfinding about the results of the action" (Lewin 1946: 38). In other words, after identifying a problem, one must analyse the situation and this will lead to a diagnosis of the problem. Afterwards 
action must be first thoroughly planned, then taken and finally evaluated on the basis of the changed produced. Maybe the most interesting part is the action implementing step which produces change. This had been already conceptualised by Lewin himself before anyone had ever talked about actionresearch (Lewin 1936). In this contribution, he identified three stages for change, which were named 'unfreezing', 'change' or intervention, and 'refreezing'.

The first stage was unfreezing agents' commitment to existing social norms. Since the norms of the field are incorporated in the agents' personality (or habitus), the problem cannot be solved unless there is a determined will to change one's own attachment to the group's cultural norms. This unfreezing was carried out by providing the group with data about the wrongful results of its negative norms. Thus, confrontation with and awareness of negative patterns would lower the agents' commitment to the existing norms.

Once the agent is open to change, the next step would be to provide the group with an alternative. In this moment, the researchers must introduce a shift in the ways agents perceive, judge, feel, act and react. This shift should be previously designed to facilitate new positive norms to be consolidated in the field. This is a cognitive restructuring of the field, a reconstruction of habiti, which is a very instable moment for agents. Here, researchers must support the subjects with all their strength, they should "create and focus energy and meaningful language because they are the scarcest resources during periods of change" (Smith 1997).

The final step for change would be refreezing the new set of norms by stabilising the group at a new state of equilibrium. Once the group reaches the desired state, policies should be implemented to support it. Otherwise the group may go back to the old norms, which are still more economic as a practice. The structure and the habiti feed each other and as long as the experience with the new norms has not already created a new state of things, a new intersubjectivity, the old norms are still subsisting and capable of coming back to the social interaction and the social relations as soon as agents relax and surrender to the structure.

\section{Can we make the change happen?}

The change, though unstable and difficult to accomplish, is very powerful and, as long as it is well cared for, it may produce very positive results. However, this methodology is simply inapplicable to a whole social field, and research must focus on smaller groups which can be controlled and cared for. Despite its being quite an important limitation, this gives us the chance to test the efficiency of planned changed without any excessive cost, which therefore makes it feasible. In the field of sworn translating and interpreting, several actions can be designed for this reduced sphere. Although we have not yet finished the description phase, the proposals which I will outline here are some of the actions suggested from the results obtained in previous works (Monzó 2002). These actions try to invest existing capital in order to obtain new assets (mainly social assets) and widen the scope of the profession. They focus on changing the balance of capitals within the group and working on distinction from other groups.

- Increasing the profession's prestige by investing in social capital (working on an idealised professional culture by promoting translators and interpreters to appear as characters in fiction, publishing anecdotes in mass media, granting a more prominent position for news related to translators' actions in wars, international negotiations, and so forth).

- Improving performance by facilitating the use of CAT tools by creating and distributing databases and by offering low-cost training sessions.

- Spreading shared knowledge through the standardisation of transgenres (within reasonable limits) for both sworn translation and interpreting. ${ }^{5}$

- Changing the habiti of professionals to reinterpret the importance of the different capitals in the field. 
- Allowing the public to recognise quality in training (promoting credentialism) and performance (adding symbolism to practice) to promote the creation of a jurisdiction for professionals.

- Promoting a shared identity by creating communication opportunities for professional translators and interpreters.

- Changing the habiti of professionals to reinterpret their positions in society.

- Promoting distinction from other fields by spreading the use of specialised concepts and language among professionals in their interactions with clients.

Of course these are only a few suggestions of actions which may be implemented and evaluated if we want to promote translators' and interpreters' interests in society. Further actions may come from a thorough knowledge of the social practice in the field of professional translation and interpreting. We have taken this as our responsibility for the Spanish market, although we are very aware that comparison with other cultures is essential for a complete knowledge of the possibilities available. On this matter we should remark the relevance of the contributions to Baker's 1998 (b) volume, the studies by Magalhães in Portugal (Magalhães 1996) and by Inghillieri in England (Inghilleri 2003). All in all, this line of study and work has not been developed to a state from which we can say we know the social practice of our field, although the panorama offers plenty of hope and very interesting opportunities to implement changes.

\section{NOTES}

1. This research is included in the work carried out by the GITRAD research group, which is currently involved in the description of the social field of legal translators and interpreters within the framework of the ACTIVE project funded by Fundación Bancaja (P1 1A2004-20). The author is also a member of the GENTT group (BFF2002-01932). 2. To cut a long story short, I interviewed some official sworn translators who held a relevant position in the field, as part of the administrative elite, the knowledge elite and also rank-and-file professionals. This helped me design a small questionnaire which I sent to those official sworn translators listed with the authorities (Spanish Department of Foreign Affairs and Catalan Department of Culture). At the same time, I asked these professional translators to send me a short translation for which I provided both a source text and brief.

3. For an application of these concepts to the translators of specialised texts, see Monzó 2003.

4. A strategy to increase capital would be, for instance, to widen the scope of influence and cover the whole spectrum of intercultural communication. This may help us distinguish ourselves from other professions and thereby help us establish a well-defined jurisdiction. On the other hand, new types of capital could be acquired by investing economic capital in obtaining social capital (advertising campaigns, for example).

5. The GITRAD group is already working on a knowledge base to share professionals' expertise. See Borja (2005) and Monzó (2005c).

\section{REFERENCES}

Аввот, A. (1988): The System of Professions: An Essay on the Division of Expert Labor, Chicago, University of Chicago Press.

ABEL, R. L. (1989): American Lawyers, New York, Oxford University Press.

BAKER, M. (1998a): "Réexplorer la langue de la traduction: une approche par corpus", Meta 43-4, pp. 480-485.

- (ed.) (1998b): The Routledge Encyclopedia of Translation Studies, London, Routledge.

BORJA, A. (2005): "Organización del conocimiento para la traducción jurídica", I. GARCÍA IZQUIERDO (ed.): El

género textual y la traducción. Reflexiones teóricas y aplicaciones pedagógicas. Bern, Peter Lang.

BouRdieu, P. (1971): "Genèse et structure du champ religieux", Revue française de sociologie 12, pp. 295-334.

- (1972): Esquisse d'une théorie de la pratique, précédée de trois études d'ethnographie kabyle, Geneve, Droz.

- (1979): "Les trois états du capital culturel", Actes de la recherche en sciences sociales 30, pp. 3-6. 
- (1986): "La force du droit", Actes de la recherche en sciences sociales 64.

CARR-SAunders, A. M. and P. A. Wilson (1933): The Professions, Oxford, Oxford University Press.

CoreY, S. (1953): Action Research to Improve School Practice, New York, Teachers College, Columbia

University.

Delisle, J. (1998): "Canadian Tradition", M. BAKER (ed.): The Routledge Encyclopedia of Translation Studies.

London, Routledge, pp. 356-365.

Durkheim, É. (1937/1992): Professional Ethics and Civic Morals, London, Routledge.

- (1938/1977): The Evolution of Educational Thought: Lectures on the Formation and Development of Secondary

Education in France, London, Routledge and Kegan Paul.

EsCuDERO, A. (2001): "La comisaría de Málaga ha utilizado 'ilegales' detenidos como intérpretes", in La Gaceta de

Málaga, pp. 40, Malaga.

FREIDSON, E. (1986): Professional Powers. A Study of the Institutionalization of Formal Knowledge, Chicago, London, University of Chicago Press.

HASKell, T. L. (ed.) (1984): The Authority of Experts: Studies in History and Theory, Interdisciplinary Studies in History, Bloomington, Indiana University Press.

HAtim, B. (2001): Teaching and Researching Translation, Applied linguistics in Action, Harlow, Pearson

Education.

HustLeR, D., A. CASSIDY and T. CUFF (eds.) (1986): Action Research in Classrooms and Schools, London, Allen \& Unwin.

INGHILLERI, M. (2003): "Habitus, Field and Discourse: Interpreting as a Socially Situated Activity", Target:

International Journal on Translation Studies 15-2, pp. 243-268.

KIRALY, D. (2001): "Towards a Constructivist Approach to Translator Education", Quaderns Revista de traducció

6, pp. 50-53.

LARSON, M. S. (1977): The Rise of Professionalism: A Sociological Analysis, Berkeley and London, University of

California Press.

LewIn, K. (1936): Principles of Topological Psychology, New York, McGraw-Hill.

- (1946): "Action-research and Minority Problems", Journal of Social Issues 2-4, pp. 34-46.

Magalhães, F. J. (1996): Da tradução profissional em Portugal, Lisbon, Colibri.

Millerson, G. (1964): The Qualifying Associations: A Study in Professionalisation, London, Routledge.

MonZó, E. (2002): La professió del traductor jurídic i jurat. Descripció sociològica de la professió $i$ anàlisi

discursiva del transgènere, Departament of Translation and Communication, Universitat Jaume I, Ph.D. thesis.

- (2003): "Las socializaciones del traductor especializado: El papel de los géneros", Revista de la Facultad de

Lenguas Modernas 6, pp. 15-29.

- (2005a): "Investigar con los profesionales: colaboraciones de investigación-acción", Anabel BoRJA and Esther

MonZó (eds.): Traducción y mediación en las relaciones jurídicas internacionales, Castelló de la Plana, Universitat Jaume I

- (2005b): "Reeducación y desculturación a través de géneros en la traducción jurídica, económica y administrativa",

I. GARCÍA IZQUIERDO (ed.): El género textual y la traducción. Reflexiones teóricas y aplicaciones pedagógicas,

Bern, Peter Lang.

- (2005c): "Cómo traducir derecho sin ser jurista: nuevas fuentes y métodos documentales para la traducción

jurídica", D. SAlES SAlvador (ed.): La biblioteca de Babel, Granada, Comares

PARKIN, F. (1974): "Strategies of Social Closure in Class Formation", in The Social Analysis of Class Structure,

London, Tavistock Publications.

Peñarroja, J. (2004): "Nota sobre demanda contra la Agencia Maremagnum", Butlletí de l'Associació de

Traductors i Intèrpres Jurats de Catalunya, December.

PERKIn, H. J. (1989): The Rise of Professional Society: England since 1880, London, New York, Routledge.

SAPIRO, G. (1999): La guerre des écrivains: 1940-1953, Paris, Fayard.

Simeoni, D. (1998): "The Pivotal Status of the Translator's Habitus", Target 10-1, pp. 1-39.

SMITH, D. K. (1997): Taking Charge of Change: 10 Principles for Managing People and Performance, Don Mills, Addison-Wesley.

WEBER, M. (1925/1976): Wirtschaft und Gesellschaft, Tübingen, Mohr.

WILENSKY, H. L. (1964): "The Professionalization of Everyone?" The American Journal of Sociology 70, pp. 137158. 